\title{
Article \\ A DFT/PCM Study on the Affinity of Salinomycin to Bind Monovalent Metal Cations
}

\author{
Todor Dudev ${ }^{1, *}$, Diana Cheshmedzhieva ${ }^{1}\left(\mathbb{D}\right.$, Peter Dorkov $^{2}$ and Ivayla Pantcheva ${ }^{3, *}$ \\ 1 Laboratory of Computational Chemistry and Spectroscopy, Faculty of Chemistry and Pharmacy, \\ "St. Kl. Ohridski" University of Sofia, 1164 Sofia, Bulgaria; dvalentinova@gmail.com \\ 2 Research \& Development Department, Biovet Ltd., 4550 Peshtera, Bulgaria; p_dorkov@abv.bg \\ 3 Laboratory of Biocoordination and Bioanalytical Chemistry, Faculty of Chemistry and Pharmacy, \\ "St. K1. Ohridski" University of Sofia, 1164 Sofia, Bulgaria \\ * Correspondence: t.dudev@chem.uni-sofia.bg (T.D.); ipancheva@chem.uni-sofia.bg (I.P.); \\ Tel.: +359-2-816-1323 (T.D.); +359-2-816-1446 (I.P.)
}

check for updates

Citation: Dudev, T.;

Cheshmedzhieva, D.; Dorkov, P.;

Pantcheva, I. A DFT/PCM Study on

the Affinity of Salinomycin to Bind

Monovalent Metal Cations. Molecules 2022, 27, 532. https://doi.org/ 10.3390/molecules27020532

Academic Editor: Julia Romanova

Received: 23 December 2021

Accepted: 11 January 2022

Published: 14 January 2022

Publisher's Note: MDPI stays neutral with regard to jurisdictional claims in published maps and institutional affiliations.

Copyright: (C) 2022 by the authors. Licensee MDPI, Basel, Switzerland. This article is an open access article distributed under the terms and conditions of the Creative Commons Attribution (CC BY) license (https:// creativecommons.org/licenses/by/ $4.0 /)$.

\begin{abstract}
The affinity of the polyether ionophore salinomycin to bind IA/IB metal ions was accessed using the Gibbs free energy of the competition reaction between SalNa (taken as a reference) and its rival ions: $\left[\mathrm{M}^{+}\right.$-solution $]+[$SalNa $] \rightarrow[\mathrm{SalM}]+\left[\mathrm{Na}^{+}\right.$-solution $](\mathrm{M}=\mathrm{Li}, \mathrm{K}, \mathrm{Rb}, \mathrm{Cs}, \mathrm{Cu}, \mathrm{Ag}, \mathrm{Au})$. The DFT/PCM computations revealed that the ionic radius, charge density and accepting ability of the competing metal cations, as well as the dielectric properties of the solvent, have an influence upon the selectivity of salinomycin. The optimized structures of the monovalent metal complexes demonstrate the flexibility of the ionophore, allowing the coordination of one or two water ligands in SalM- $W_{1}$ and SalM- $W_{2}$, respectively. The metal cations are responsible for the inner coordination sphere geometry, with coordination numbers spread between $2\left(\mathrm{Au}^{+}\right), 4\left(\mathrm{Li}^{+}\right.$and $\left.\mathrm{Cu}^{+}\right), 5 / 6\left(\mathrm{Na}^{+}, \mathrm{K}^{+}\right.$, $\left.\mathrm{Ag}^{+}\right), 6 / 7\left(\mathrm{Rb}^{+}\right)$and $7 / 8\left(\mathrm{Cs}^{+}\right)$. The metals' affinity to salinomycin in low-polarity media follows the order of $\mathrm{Li}^{+}>\mathrm{Cu}^{+}>\mathrm{Na}^{+}>\mathrm{K}^{+}>\mathrm{Au}^{+}>\mathrm{Ag}^{+}>\mathrm{Rb}^{+}>\mathrm{Cs}^{+}$, whereas some derangement takes place in high-dielectric environment: $\mathrm{Li}^{+} \geq \mathrm{Na}^{+}>\mathrm{K}^{+}>\mathrm{Cu}^{+}>\mathrm{Au}^{+}>\mathrm{Ag}^{+}>\mathrm{Rb}^{+}>\mathrm{Cs}^{+}$.
\end{abstract}

Keywords: salinomycin; IA/IB metal ions; monovalent metal complex; DFT/PCM

\section{Introduction}

Salinomycin is a polyketide ionophore extracted from Streptomyces albus [1]. It exerts an anticoccidial effect against all Eimeria species known as causative agents of coccidiosis in poultry as well as in the other farm animals [2-4]. It is also effective in treating bacterial, parasitic and some viral infections [5-7]. The biological activity of salinomycin is primarily based on its ability to form lipophilic complexes with the monovalent alkaline ions, making the membranes of target cells permeable to the ions mentioned. In this way, the intracellular cation concentration in the cells is disturbed, leading to a cascade of energy-consuming processes and ultimate cell death.

Recently salinomycin has re-attracted attention in the biomedical field due to its selective inhibition of cancer stem cells in a variety of types of cancer. The exact mode of action of the antibiotic is not yet known, but there are multiple pathways by which it may inhibit tumor growth, including interference with the Akt signaling pathway, Wnt/ $\beta$ catenin, Hedgehog, and Notch pathways of cancer progression [8-22].

Salinomycinic acid $(\mathrm{SalH}$, Scheme 1) is a polyether polyalcohol monocarboxylic acid and its structure determines the ionophoric action of the antibiotic. The polyether chain contains a number of externally oriented alkyl substituents thus defining the overall lipophilic character of the drug. The weak interaction (H-bond formation) between the carboxylic and hydroxyl groups placed on the opposite ends of the molecule causes folding of the structure with the formation of a hydrophilic cavity due to the internally placed polyether oxygen atoms. This core is able to accommodate water molecules $(\mathrm{SalH})$ or monovalent 
alkali ions $\left(\mathrm{M}^{+}\right)$preceded by the initial deprotonation of the carboxylic function (SalM). Compared to the polyether ionophorous analog monensin [23-30], only a single structural report on the salinomycin sodium complex (Figure 1) is available [31]. Moreover, although referred to as a potassium ionophore [32], in contrast to the sodium ionophore monensin, no systematic study on salinomycin's selectivity towards the monovalent metal cations has been found in the literature.

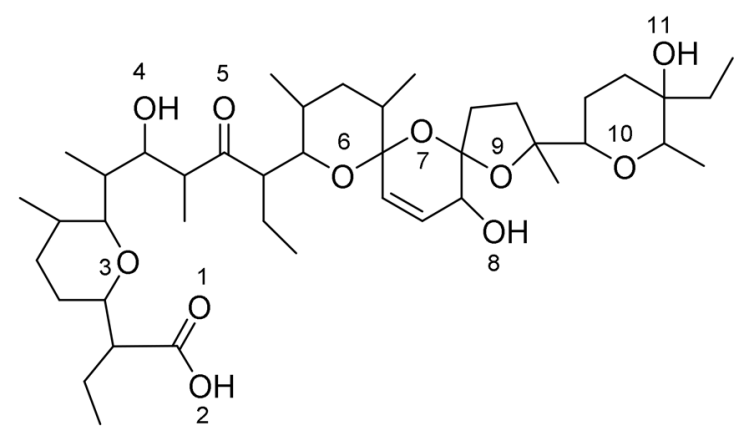

Scheme 1. Chemical structure of salinomycinic acid with the numbering sequence of oxygen atoms.

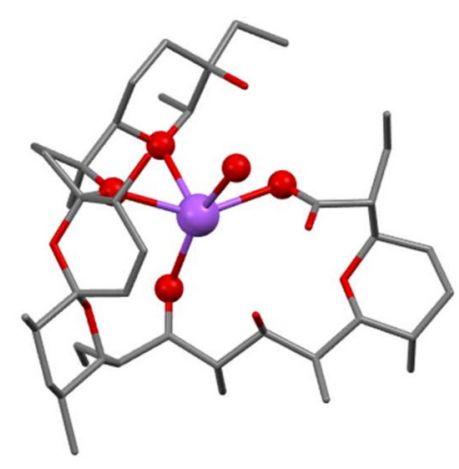

(a)

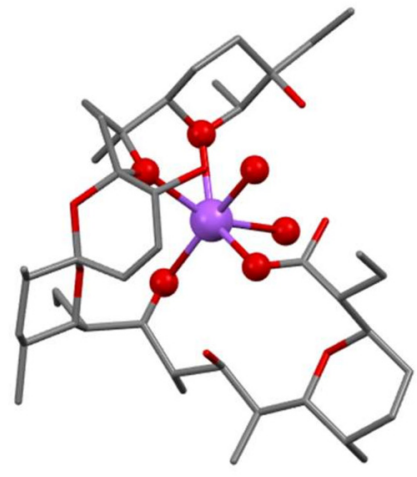

(b)

Figure 1. Crystal structure of sodium salinomycinate (SalNa) containing (a) one and (b) two water ligands [31]. Color scheme: $\mathrm{C}$-grey, $\mathrm{O}-$ red, $\mathrm{Na}$-purple (hydrogens are omitted for clarity).

Due to the very limited number of crystallographic structural data on metal complexes of salinomycin and lack of substantial knowledge on its affinity to bind metal cations, here, we highlight the factors which may influence the ability of the antibiotic to form coordination compounds with monovalent metal ions. For the first time, we employed the density functional theory (DFT) calculations combined with polarizable continuum model (PCM) computations to evaluate the free energies of complex formation between the salinomycinate anion and groups IA/IB metal ions. The quantum chemical study brought out the origin of the metal cation (radius, charge, accepting ability) and the dielectric properties of the environment as parameters that affect the coordination properties of the ionophore.

\section{Results and Discussion}

The metal(I)-loaded constructs of salinomycin were modeled according to the only available crystal structures of sodium salinomycinate (SalNa) [31]. Two types of complex species have been observed experimentally differing by the number of water molecules coordinated to $\mathrm{Na}^{+}$ions in the binding site: a complex with one crystal water $\left(\mathrm{SalNa}-\mathrm{W}_{1}\right)$ and its counterpart comprising two water molecules orbiting the metal cation $\left(\mathrm{SalNa}-\mathrm{W}_{2}\right)$. Accordingly, the atomic coordinates of the respective experimental constructs were taken and used in subsequent geometry optimizations. Then, the $\mathrm{Na}^{+}$cation (used as a reference) 
in the optimized structures was replaced by $\mathrm{M}^{+}$cations and the respective SalM- $\mathrm{W}_{1 / 2}$ structures were subjected to succeeding quantum-chemical calculations. The optimized structures of the entire series of SalNa $/ \mathrm{M}-\mathrm{W}_{1} / \mathrm{W}_{2}$ complexes are given in Figures 2-4.

$\mathrm{Li}^{+}\left(\mathrm{W}_{1}\right)$

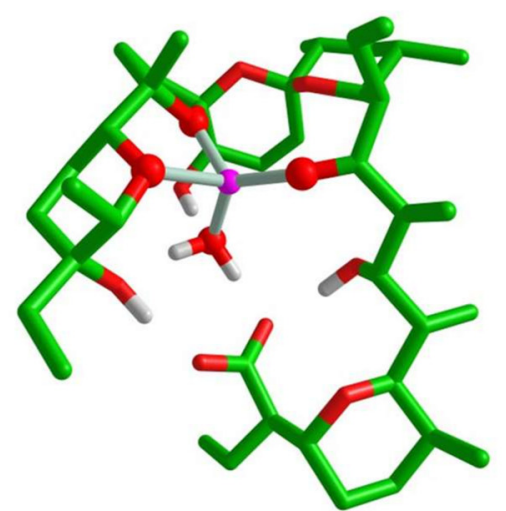

$\mathrm{K}^{+}\left(\mathrm{W}_{1}\right)$

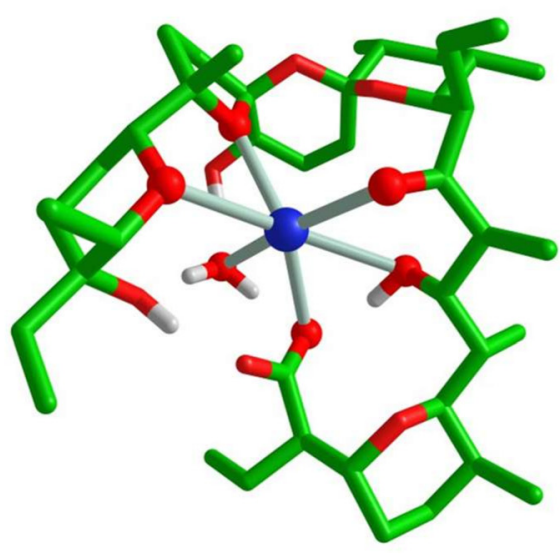

$\mathrm{Na}^{+}\left(\mathrm{W}_{1}\right)$

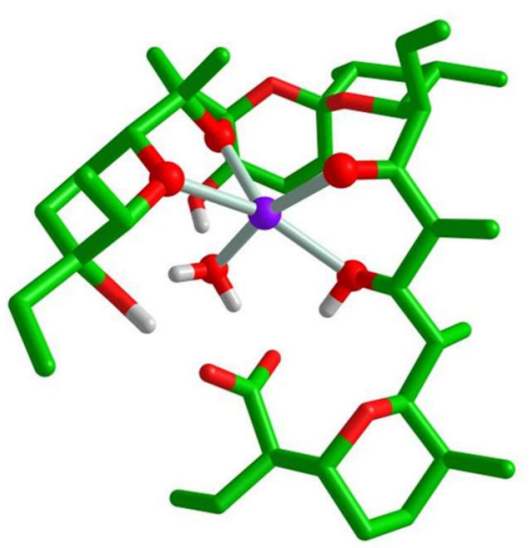

$\mathbf{R b}^{+}\left(\mathbf{W}_{1}\right)$

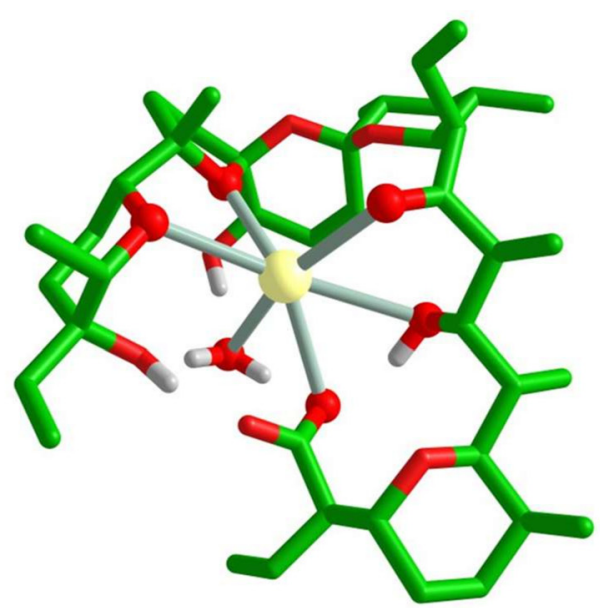

$\mathrm{Cs}^{+}\left(\mathrm{W}_{1}\right)$

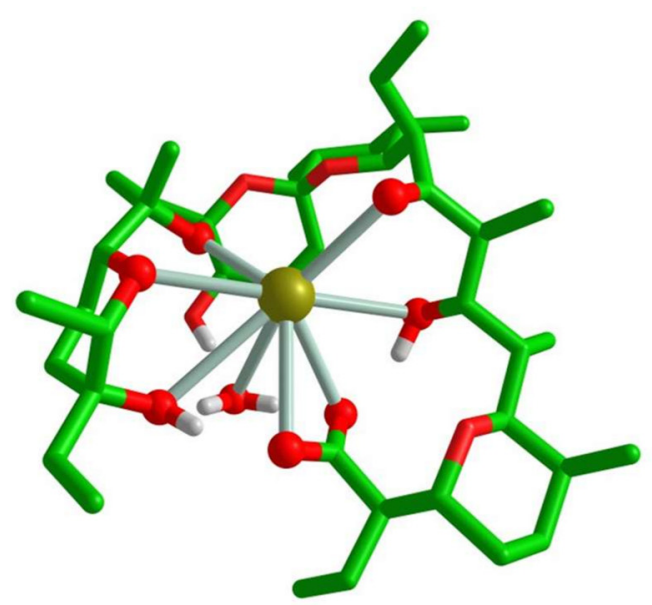

Figure 2. B3LYP/6-31+G(d,p) fully optimized structures of salinomycin complexes with $\mathrm{Li}^{+}, \mathrm{Na}^{+}$, $\mathrm{K}^{+}, \mathrm{Rb}^{+}$and $\mathrm{Cs}^{+}$cations, containing one $\left(\mathrm{W}_{1}\right)$ water molecule. Color scheme: $\mathrm{C}$ - green, $\mathrm{O}-\mathrm{red}$, $\mathrm{H}$-light grey, Li-magenta, $\mathrm{Na}$ - purple, $\mathrm{K}$ - blue, $\mathrm{Rb}$-yellow, $\mathrm{Cs}$ - deep olive (carbon hydrogens are omitted for clarity). 
$\mathbf{L i}^{+}\left(\mathbf{W}_{2}\right)$

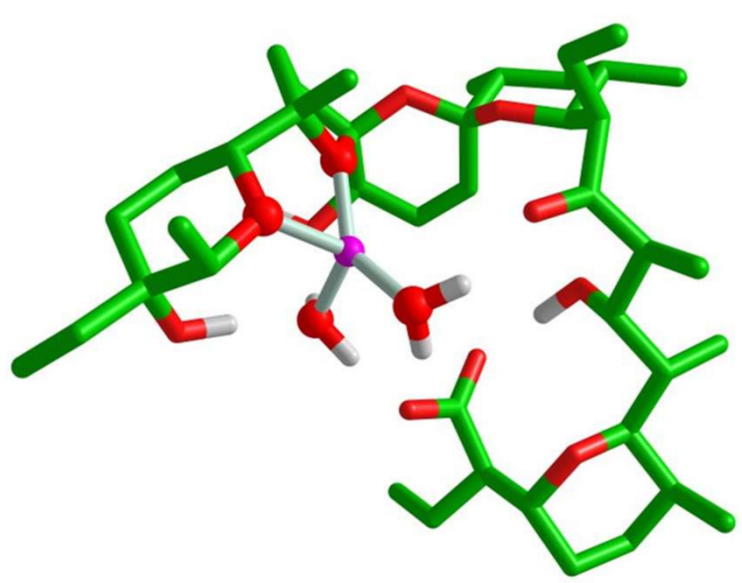

$\mathrm{K}^{+}\left(\mathrm{W}_{2}\right)$

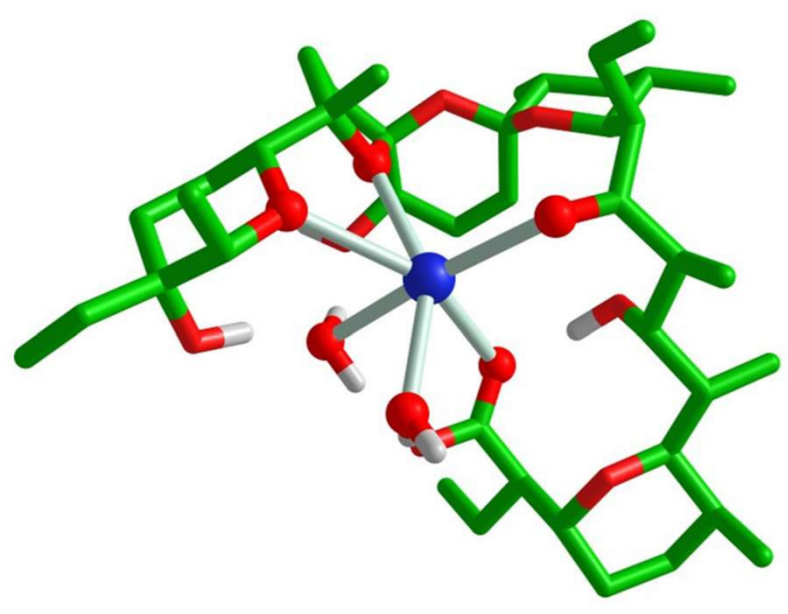

$\mathrm{Na}^{+}\left(\mathrm{W}_{2}\right)$

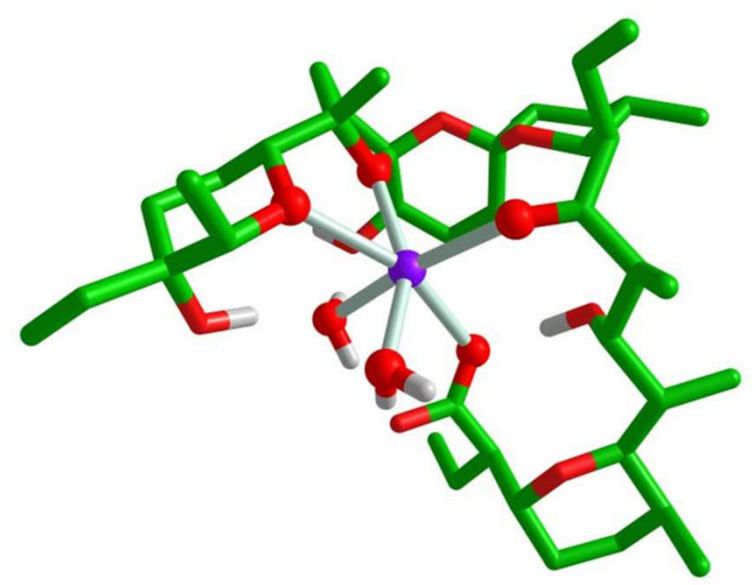

$\mathrm{Rb}^{+}\left(\mathrm{W}_{2}\right)$

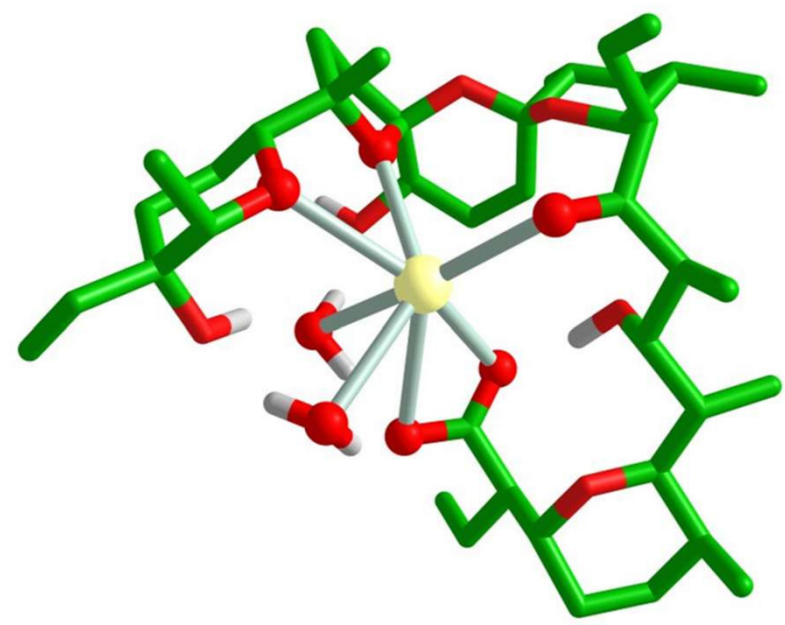

$\mathrm{Cs}^{+}\left(\mathrm{W}_{2}\right)$

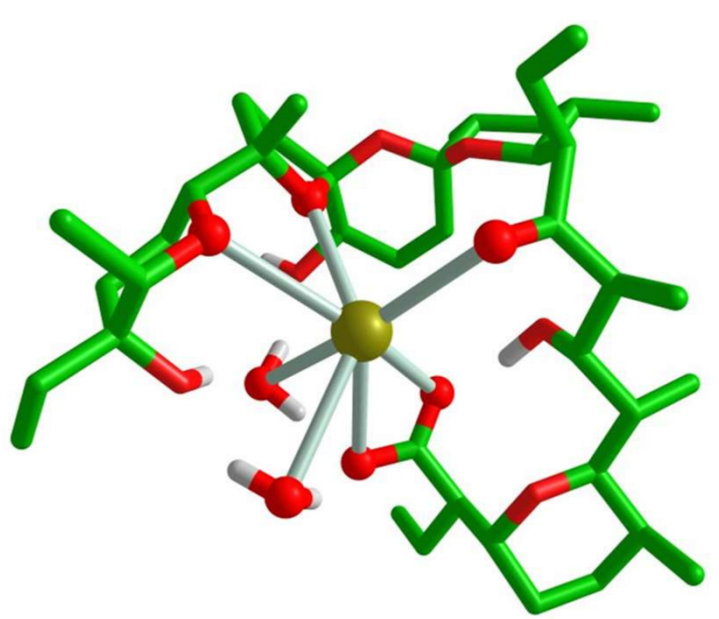

Figure 3. B3LYP/6-31+G(d,p) fully optimized structures of salinomycin complexes with $\mathrm{Li}^{+}, \mathrm{Na}^{+}$, $\mathrm{K}^{+}, \mathrm{Rb}^{+}$, and $\mathrm{Cs}^{+}$cations, containing two $\left(\mathrm{W}_{2}\right)$ water molecules. Color scheme: $\mathrm{C}$-green, $\mathrm{O}-$ red, $\mathrm{H}$-light grey, $\mathrm{Li}-$ magenta, $\mathrm{Na}$ - purple, $\mathrm{K}-$ blue, $\mathrm{Rb}-$ yellow, $\mathrm{Cs}$ - deep olive (carbon hydrogens are omitted for clarity). 


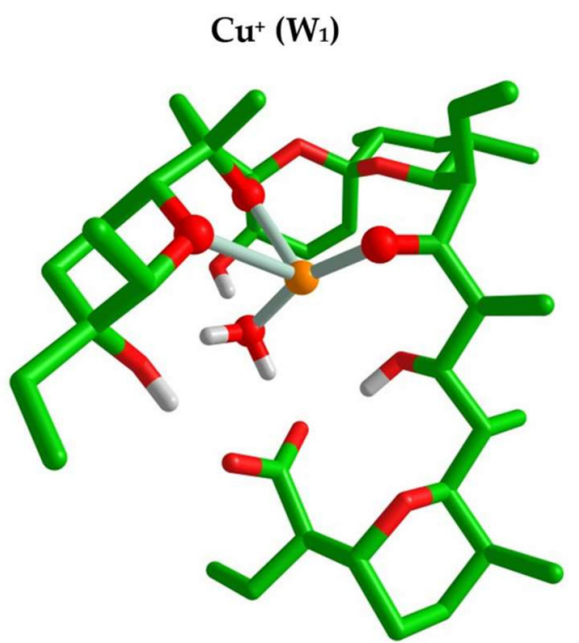

$\mathrm{Ag}^{+}\left(\mathrm{W}_{1}\right)$

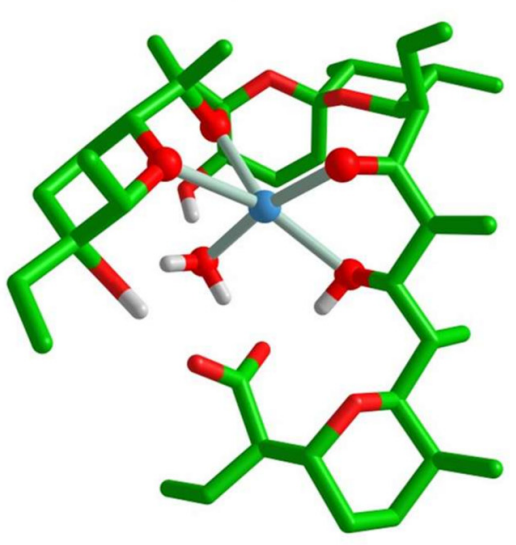

$\mathrm{Au}^{+}\left(\mathrm{W}_{1}\right)$

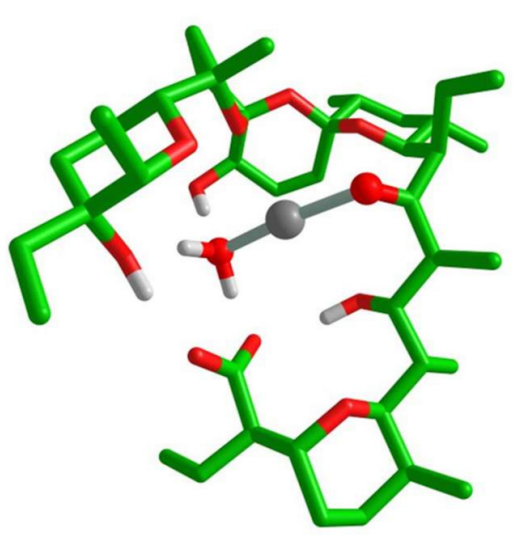

(a)

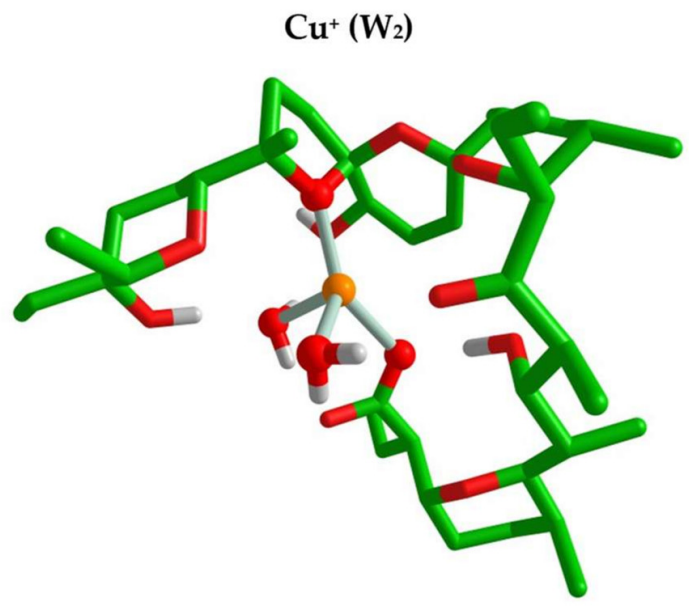

$\mathrm{Ag}^{+}\left(\mathrm{W}_{2}\right)$

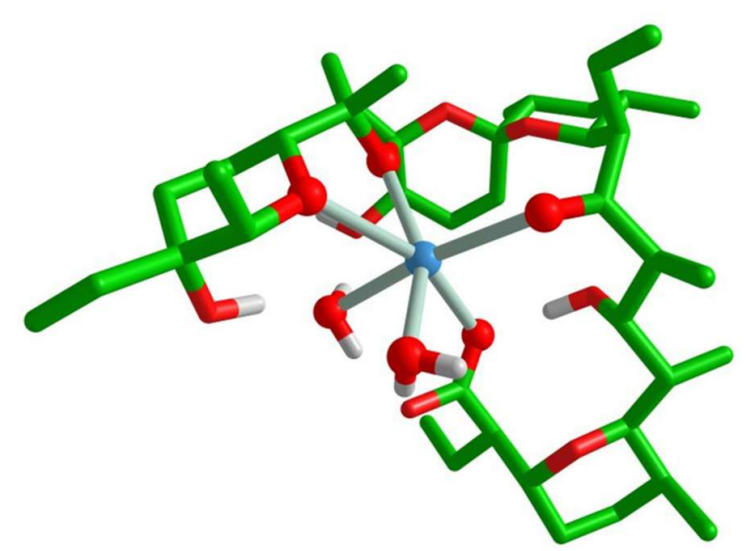

$\mathrm{Au}^{+}\left(\mathrm{W}_{2}\right)$

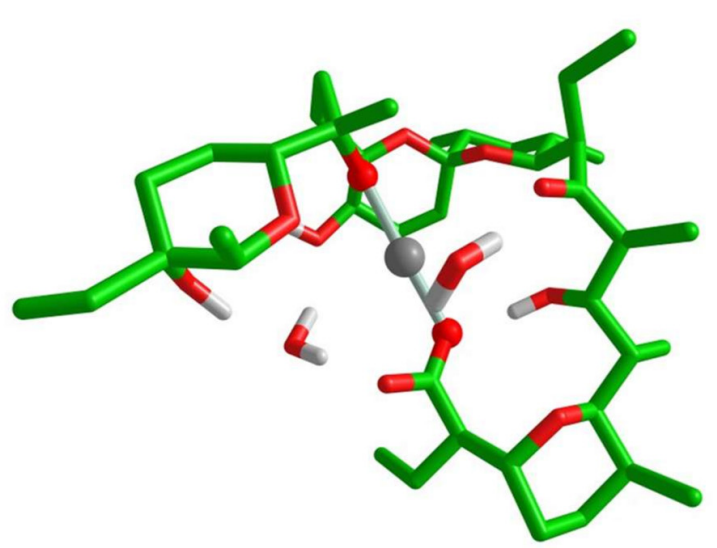

(b)

Figure 4. B3LYP $/ 6-31+\mathrm{G}(\mathrm{d}, \mathrm{p})$ fully optimized structures of salinomycin complexes with $\mathrm{Cu}^{+}, \mathrm{Ag}^{+}$, and $\mathrm{Au}^{+}$, containing $(\mathbf{a})$ one $\left(\mathrm{W}_{1}\right)$ and $(\mathbf{b})$ two $\left(\mathrm{W}_{2}\right)$ water molecules. Color scheme: $\mathrm{C}$ - green, $\mathrm{O}-\mathrm{red}$, $\mathrm{H}$-light grey, $\mathrm{Cu}$ —orange, Ag—light blue, Au—gray (carbon hydrogens are omitted for clarity).

The affinity of salinomycin towards monovalent metal cations was evaluated modeling the competition Equation (1), where $\mathrm{Na}^{+}$, bound to the host ligand, is replaced by its 
competitor, $\mathrm{M}^{+}(\mathrm{M}=\mathrm{Li}, \mathrm{K}, \mathrm{Rb}, \mathrm{Cs}, \mathrm{Cu}, \mathrm{Ag}$, and $\mathrm{Au})$ in an environment with a different dielectric constant $\varepsilon$ :

$$
\left[\mathrm{M}^{+} \text {-solution }\right]+[\text { SalNa }] \rightarrow[\text { SalM }]+\left[\mathrm{Na}^{+} \text {-solution }\right]
$$

[SalNa/M] and $\left[\mathrm{M}^{+} / \mathrm{Na}^{+}\right.$-solution] represent the metal ion, coordinated to salinomycinate anion, and the corresponding ligand-free metal ion in solution, respectively. The outcome of the rivalry between the monovalent cations from groups IA and IB and their fellow congener $\mathrm{Na}^{+}$for the ionophore was assessed by computing the Gibbs free energy change, $\Delta G^{\varepsilon}$, of Equation (1).

\subsection{Salinomycin Complexes with Alkali Metal Ions}

Optimized structures of salinomycin complexes with $\mathrm{Li}^{+}, \mathrm{Na}^{+}, \mathrm{K}^{+}, \mathrm{Rb}^{+}$, and $\mathrm{Cs}^{+}$, containing one $\left(W_{1}\right)$ and two $\left(W_{2}\right)$ water molecules in the binding site, are shown in Figures 2 and 3. The host salinomycin donates oxygen atoms from the ether, hydroxyl, carbonyl, and carboxylate groups in forming the metal complexes. The analysis of the structures presented reveals that the host ionophore is flexible and able to adapt to the specific physico-chemical properties of the guest metal ion species. The smallest member of the alkali group, $\mathrm{Li}^{+}$, adopts its preferred tetrahedral coordination sphere in both $\mathrm{W}_{1}$ and $\mathrm{W}_{2}$ series with a mean Li-O bond distance of $1.984 / 1.962 \AA$, respectively. The constructs with the heavier metals and one crystal water form penta- $\left(\mathrm{SalNa}-\mathrm{W}_{1}\right)$, six- $\left(\mathrm{SalK}-\mathrm{W}_{1}\right.$, SalRb-W $W_{1}$, and eight-coordinated $\left(\right.$ SalCs- $\left.W_{1}\right)$ complexes with increased metal-oxygen bond distances going down the group: $2.407,2.852,2.985$, and $3.211 \AA$ for $\mathrm{Na}^{+}, \mathrm{K}^{+}, \mathrm{Rb}^{+}$, and $\mathrm{Cs}^{+}$, respectively. The main trend-increasing the coordination number $(\mathrm{CN})$ and elongating the metal-oxygen bond distances with increasing the atomic number of the metal-is similar in the two-water SalM series.

However, as compared to the $W_{1}$ complexes, the metal coordination numbers differ in SalNa-W $2(C N=6), S a l R b-W_{2}(C N=7)$ and SalCs- $W_{2}(C N=7)$. The respective metaloxygen bond lengths in the $\mathrm{W}_{2}$ series are $2.511\left(\right.$ SalNa- $\left.\mathrm{W}_{2}\right), 2.814\left(\mathrm{SalK}-\mathrm{W}_{2}\right), 3.055(\mathrm{SalRb}-$ $W_{2}$ ), and 3.264 (SalCs- $\left.W_{2}\right) \AA$. In both the $W_{1}$ and $W_{2}$ series, the M-O bond elongation is compatible with the increased metal cation radius (cation bulkiness) with increasing the atomic number: $0.59 \AA$ for tetra-coordinated lithium, $1.00 / 1.02 \AA$ for penta-/hexa-coordinated sodium, $1.38 \AA$ for hexa-coordinated potassium, 1.52/1.56 $\AA$ for hexa-/hepta-coordinated rubidium and $1.74 \AA$ for octa-coordinated cesium [33] (Table 1). Water molecules stay firmly coordinated to the metal cation in all the complexes.

Table 1. Structural and thermodynamic characteristics of alkali and coinage metal cations.

\begin{tabular}{|c|c|c|c|c|}
\hline Cation & Ionic Radius (r, ̊̊) [33] ${ }^{1}$ & $\begin{array}{c}\text { Charge Density } \\
\left(\mathrm{e} / \AA^{3}\right)\end{array}$ & $\begin{array}{c}\text { Lewis Acidity } \\
\text { (Valence Units) [34] }\end{array}$ & $\begin{array}{c}\text { Charge Transfer to the } \\
\text { Metal }^{3} \text { (e) }\end{array}$ \\
\hline $\mathrm{Li}^{+}$ & 0.59 (IV) & 1.16 & 0.215 & $0.286 / 0.260$ \\
\hline $\mathrm{Na}^{+}$ & $1.00 / 1.02(\mathrm{~V} / \mathrm{VI})$ & $0.24 / 0.22$ & 0.159 & $0.215 / 0.198$ \\
\hline $\mathrm{K}^{+}$ & $1.38(\mathrm{VI})$ & 0.09 & 0.108 & $0.166 / 0.152$ \\
\hline $\mathrm{Rb}^{+}$ & $1.52 / 1.56(\mathrm{VI} / \mathrm{VII})$ & $0.07 / 0.06$ & 0.099 & $0.142 / 0.132$ \\
\hline $\mathrm{Cs}^{+}$ & -/1.74 (VII/VIII) & $-/ 0.04$ & 0.084 & $0.129 / 0.119$ \\
\hline $\mathrm{Cu}^{+}$ & 0.60 (IV) & 1.10 & 0.400 & $0.360 / 0.338$ \\
\hline $\mathrm{Ag}^{+}$ & $1.09 / 1.15(\mathrm{~V} / \mathrm{VI})$ & $0.18 / 0.16$ & 0.191 & $0.300 / 0.281$ \\
\hline $\mathrm{Au}^{+}$ & $-/ 1.37$ (II/VI) & $-/ 0.09$ & - & $0.412 / 0.381$ \\
\hline
\end{tabular}

${ }^{1}$ The respective coordination number(s) of the metal is/are given in parentheses; ${ }^{2}$ Charge density $=$ Ion charge/Ion volume $=1 /\left(4 / 3 \pi \mathrm{r}^{3}\right) ;{ }^{3}$ Charge transfer from $\mathrm{CH}_{3} \mathrm{OCH}_{3}$ (model for an ether group) and $\mathrm{CH}_{3} \mathrm{OH}$ (model for a hydroxyl group) evaluated at B3LYP/6-31+G(d,p) level [35].

The thermodynamic outcome of the competition between $\mathrm{Na}^{+}$(serving as a reference cation throughout the paper) and other metal species for binding salinomycin is encoded in the Gibbs free energies of metal substitution, given in Table 2. As seen, the trends of 
changes in both the $W_{1}$ and $W_{2}$ series are quite similar with numerical values in most cases very close to each other.

Table 2. Gibbs free energies of $\mathrm{M}^{+} / \mathrm{Na}^{+}$metal substitution $\left(\Delta \mathrm{G}^{\varepsilon}, \mathrm{kcal} / \mathrm{mol}\right)$ for Equation (1), evaluated in media with different dielectric constant $\varepsilon$.

\begin{tabular}{|c|c|c|c|}
\hline Reaction & $\Delta \mathrm{G}^{\varepsilon}$ & Reaction & $\Delta \mathrm{G}^{\varepsilon}$ \\
\hline $\begin{array}{c}{\left[\mathrm{Li}^{+} \text {-solution }\right]+[\text { SalNa-W } 1] \rightarrow} \\
{\left[\text { SalLi-W }{ }_{1}\right]+\left[\mathrm{Na}^{+} \text {-solution }\right]}\end{array}$ & $\begin{array}{c}\Delta G^{1}=-21.6 \\
\Delta G^{2}=-7.8 \\
\Delta G^{4}=-3.2 \\
\Delta G^{32}=1.5 \\
\Delta G^{78}=1.4\end{array}$ & 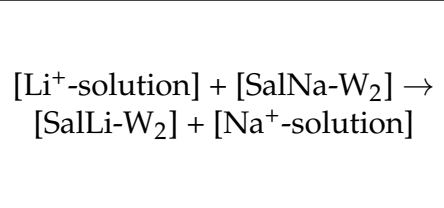 & $\begin{array}{c}\Delta G^{1}=-24.0 \\
\Delta G^{2}=-10.6 \\
\Delta G^{4}=-6.5 \\
\Delta G^{32}=-1.9 \\
\Delta G^{78}=-1.7\end{array}$ \\
\hline $\begin{array}{c}{\left[\mathrm{K}^{+} \text {-solution }\right]+\left[\text { SalNa-W } \mathrm{W}_{1}\right] \rightarrow} \\
{\left[\mathrm{SalK}_{\mathrm{K}}\right]+\left[\mathrm{Na}^{+} \text {-solution }\right]}\end{array}$ & $\begin{aligned} \Delta G^{1} & =19.8 \\
\Delta G^{2} & =9.9 \\
\Delta G^{4} & =6.8 \\
\Delta G^{32} & =2.8 \\
\Delta G^{78} & =2.8\end{aligned}$ & $\begin{array}{c}{\left[\mathrm{K}^{+} \text {-solution }\right]+\left[\mathrm{SalNa}^{-} \mathrm{W}_{2}\right] \rightarrow} \\
{[\text { SalK-W }}\end{array}$ & $\begin{array}{c}\Delta G^{1}=20.6 \\
\Delta G^{2}=10.0 \\
\Delta G^{4}=6.3 \\
\Delta G^{32}=2.7 \\
\Delta G^{78}=2.7\end{array}$ \\
\hline 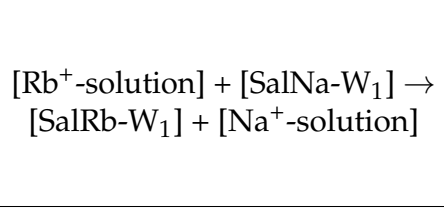 & $\begin{aligned} \Delta G^{1} & =58.2 \\
\Delta G^{2} & =46.2 \\
\Delta G^{4} & =41.6 \\
\Delta G^{32} & =34.3 \\
\Delta G^{78} & =33.2\end{aligned}$ & $\begin{array}{c}{\left[\mathrm{Rb}^{+} \text {-solution }\right]+\left[\text { SalNa-W } \mathrm{W}_{2}\right] \rightarrow} \\
{[\text { SalRb-W }]+\left[\mathrm{Na}^{+} \text {-solution }\right]}\end{array}$ & $\begin{aligned} \Delta G^{1} & =56.1 \\
\Delta G^{2} & =43.5 \\
\Delta G^{4} & =38.2 \\
\Delta G^{32} & =32.8 \\
\Delta G^{78} & =31.2\end{aligned}$ \\
\hline $\begin{array}{c}{\left[\mathrm{Cs}^{+} \text {-solution }\right]+\left[\text { SalNa-W } \mathrm{W}_{1}\right] \rightarrow} \\
{\left[\text { SalCs-W } \mathrm{W}_{1}\right]+\left[\mathrm{Na}^{+} \text {-solution }\right]}\end{array}$ & $\begin{aligned} \Delta G^{1} & =71.2 \\
\Delta G^{2} & =55.7 \\
\Delta G^{4} & =49.7 \\
\Delta G^{32} & =41.4 \\
\Delta G^{78} & =40.4\end{aligned}$ & $\begin{array}{c}{\left[\mathrm{Cs}^{+} \text {-solution }\right]+[\text { SalNa-W }} \\
\\
{\left[\text { SalCs- } \mathrm{W}_{2}\right]+\left[\mathrm{Na}^{+} \text {-solution }\right]}\end{array}$ & $\begin{aligned} \Delta G^{1} & =67.3 \\
\Delta G^{2} & =51.1 \\
\Delta G^{4} & =44.7 \\
\Delta G^{32} & =38.4 \\
\Delta G^{78} & =36.7\end{aligned}$ \\
\hline $\begin{array}{c}{\left[\mathrm{Cu}^{+} \text {-solution }\right]+[\text { SalNa-W }]} \\
\rightarrow[\text { SalCu-W }]+ \\
{\left[\mathrm{Na}^{+} \text {-solution }\right]}\end{array}$ & $\begin{array}{c}\Delta G^{1}=-34.2 \\
\Delta G^{2}=-5.8 \\
\Delta G^{4}=4.3 \\
\Delta G^{32}=9.2 \\
\Delta G^{78}=18.0\end{array}$ & $\begin{array}{c}{\left[\mathrm{Cu}^{+} \text {-solution }\right]+\left[\text { SalNa-W } \mathrm{W}_{2}\right]} \\
\rightarrow\left[\mathrm{SalCu}-\mathrm{W}_{2}\right]+ \\
{\left[\mathrm{Na}^{+} \text {-solution }\right]}\end{array}$ & $\begin{array}{c}\Delta G^{1}=-31.6 \\
\Delta G^{2}=-2.9 \\
\Delta G^{4}=7.2 \\
\Delta G^{32}=12.0 \\
\Delta G^{78}=11.4\end{array}$ \\
\hline $\begin{array}{c}{\left[\mathrm{Ag}^{+} \text {-solution }\right]+[\text { SalNa-W }} \\
\rightarrow[\text { SalAg-W }] \\
{\left[\mathrm{Wa}_{1}\right]+} \\
{\left[\mathrm{Na}^{+} \text {-solution }\right]}\end{array}$ & $\begin{aligned} \Delta G^{1} & =15.8 \\
\Delta G^{2} & =25.0 \\
\Delta G^{4} & =28.2 \\
\Delta G^{32} & =29.9 \\
\Delta G^{78} & =29.6\end{aligned}$ & $\begin{array}{c}{\left[\mathrm{Ag}^{+} \text {-solution }\right]+[\text { SalNa-W }} \\
\rightarrow\left[\text { SalAg- } \mathrm{W}_{2}\right]+ \\
{\left[\mathrm{Na}^{+} \text {-solution }\right]}\end{array}$ & $\begin{aligned} \Delta G^{1} & =16.0 \\
\Delta G^{2} & =25.3 \\
\Delta G^{4} & =28.4 \\
\Delta G^{32} & =30.1 \\
\Delta G^{78} & =29.5\end{aligned}$ \\
\hline $\begin{array}{c}{\left[\mathrm{Au}^{+} \text {-solution }\right]+\left[\text { SalNa-W } \mathrm{W}_{1}\right]} \\
\rightarrow\left[\text { SalAu- } \mathrm{W}_{1}\right]+ \\
{\left[\mathrm{Na}^{+} \text {-solution }\right]}\end{array}$ & $\begin{array}{c}\Delta G^{1}=5.2 \\
\Delta G^{2}=20.0 \\
\Delta G^{4}=24.8 \\
\Delta G^{32}=27.5 \\
\Delta G^{78}=26.8\end{array}$ & $\begin{array}{c}{\left[\mathrm{Au}^{+} \text {-solution }\right]+[\text { SalNa-W }} \\
\rightarrow\left[\text { SalAu- } \mathrm{W}_{2}\right]+ \\
{\left[\mathrm{Na}^{+} \text {-solution }\right]}\end{array}$ & $\begin{array}{c}\Delta G^{1}=0.7 \\
\Delta G^{2}=14.5 \\
\Delta G^{4}=18.5 \\
\Delta G^{32}=20.1 \\
\Delta G^{78}=18.0\end{array}$ \\
\hline
\end{tabular}

The smallest alkali cation, $\mathrm{Li}^{+}$, is the only one that can outcompete $\mathrm{Na}^{+}$(in low dielectric medium for the $W_{1}$ series and throughout the entire dielectric region in the $W_{2}$ series), evidenced by the negative values of the respective $\Delta G^{\varepsilon}$ in Table 2. Note that the competitiveness of $\mathrm{Li}^{+}$is much higher in the gas phase (very negative $\Delta \mathrm{G}^{1}$ ), where the electronic factors dominate the exchange reaction. However, the high desolvation penalty of the incoming $\mathrm{Li}^{+}(69,95,120$ and $123 \mathrm{kcal} / \mathrm{mol}$ in $\varepsilon=2,4,32$, and 78, respectively), which is higher than the solvation energy gain upon $\mathrm{Na}^{+}$release $(-54,-75,-95$, and $-98 \mathrm{kcal} / \mathrm{mol}$ [35]), attenuates the resulting $\Delta \mathrm{G}^{\varepsilon}$ in condensed media. Furthermore, heavier alkali metals $\left(\mathrm{K}^{+}, \mathrm{Rb}^{+}\right.$, and $\left.\mathrm{Cs}^{+}\right)$are weaker competitors of $\mathrm{Na}^{+}$and yield positive free energies of metal exchange which increase down the group. Thus, the affinity of the alkali metal cations for the host ionophore can be arranged in the following order: $\mathrm{Li}^{+}>\mathrm{Na}^{+}>\mathrm{K}^{+}>\mathrm{Rb}^{+}>\mathrm{Cs}^{+}$(non-polar solvents) and $\mathrm{Li}^{+} \geq \mathrm{Na}^{+}>\mathrm{K}^{+}>\mathrm{Rb}^{+}>\mathrm{Cs}^{+}$(polar solvents). These results are fully in line with the respective thermodynamic characteristics 
of these metal species summarized in Tables 1-4. The "winner" of the group, $\mathrm{Li}^{+}$, is characterized with the highest charge density and Lewis acidity, and the best charge accepting abilities. These characteristics gradually weaken for the rest of the cations, following the same affinity order as given above.

Table 3. Atom charges after the charge transfer (CT) from ligands to the metal cation in salinomycin complexes with one water molecule from Hirshfeld, CM5 and NBO population analyses (in e).

\begin{tabular}{cccc}
\hline Ion & $\mathbf{q}^{\text {hirsh }}$ & $\mathbf{q}^{\text {CM5 }}$ & $\mathbf{q}^{\text {NBO }}$ \\
\hline $\mathrm{Li}^{+}$ & 0.1746 & 0.5007 & 0.8892 \\
$\mathrm{Na}^{+}$ & 0.2600 & 0.6675 & 0.8993 \\
$\mathrm{~K}^{+}$ & 0.2773 & 0.7816 & 0.9112 \\
$\mathrm{Rb}^{+}$ & 0.3023 & 0.8319 & 0.9284 \\
$\mathrm{Cs}^{+}$ & 0.3293 & 0.9555 & 0.9454 \\
$\mathrm{Cu}^{+}$ & 0.2780 & 0.4605 & 0.7379 \\
$\mathrm{Ag}^{+}$ & 0.3224 & 0.4651 & 0.6711 \\
$\mathrm{Au}^{+}$ & 0.2805 & 0.4202 & 0.5418 \\
\hline
\end{tabular}

Table 4. Atom charges after the charge transfer (CT) from ligands to the metal cation in salinomycin complexes with two water molecules from Hirshfeld, CM5 and NBO population analyses (in e).

\begin{tabular}{cccc}
\hline Ion & $\mathbf{q}^{\text {hirsh }}$ & $\mathbf{q}^{\text {CM5 }}$ & $\mathbf{q}^{\text {NBO }}$ \\
\hline $\mathrm{Li}^{+}$ & 0.1725 & 0.5074 & 0.9005 \\
$\mathrm{Na}^{+}$ & 0.2474 & 0.6128 & 0.9121 \\
$\mathrm{~K}^{+}$ & 0.2797 & 0.7392 & 0.9277 \\
$\mathrm{Rb}^{+}$ & 0.3263 & 0.7472 & 0.9395 \\
$\mathrm{Cs}^{+}$ & 0.3546 & 0.8293 & 0.9519 \\
$\mathrm{Cu}^{+}$ & 0.2411 & 0.4046 & 0.6690 \\
$\mathrm{Ag}^{+}$ & 0.3182 & 0.4450 & 0.6687 \\
$\mathrm{Au}^{+}$ & 0.2562 & 0.3946 & 0.4588 \\
\hline
\end{tabular}

\subsection{Salinomycin Complexes with Coinage Metal Ions}

Competition between $\mathrm{Na}^{+}$and Group IB monovalent cations $\left(\mathrm{Cu}^{+}, \mathrm{Ag}^{+}\right.$, and $\left.\mathrm{Au}^{+}\right)$ was also investigated. The optimized structures of SalCu- $W_{1} / W_{2}, S a l A g-W_{1} / W_{2}$, and $\mathrm{SalAu}-\mathrm{W}_{1} / \mathrm{W}_{2}$ are shown in Figure 4.

Copper cation forms tetrahedral complexes in both $W_{1}$ and $W_{2}$ series with average Cu-O bond distances of 2.220/2.211 $\AA$, respectively. Due to its high charge density and Lewis acidity, as well as strong charge accepting ability (Tables $1-4), \mathrm{Cu}^{+}$ions outcompetes $\mathrm{Na}^{+}$in both the gas phase and nonpolar solvents such as cyclohexane $(\varepsilon \approx 2)$. In more polar solvents, however, the trend changes: because of solvation effects (see above), $\mathrm{Na}^{+}$ complex becomes dominant over its $\mathrm{Cu}^{+}$counterpart in higher-polarity solvents (positive $\Delta G^{4}, \Delta G^{32}$, and $\Delta G^{78}$ ).

Expectedly, the metal coordination number in silver complexes increases (to 5 in SalAg- $W_{1}$ and 6 in SalAg- $W_{2}$ ) with concomitant increase in the respective $\Delta$ Gs which stay on a positive ground throughout the entire dielectric range (Table 2). In contrast, $\mathrm{Au}^{+}$coordination number sharply decreases to 2 (linear configuration) due to the strong relativistic effects [36]. Data collected in Table 2 imply that, although $\mathrm{Au}^{+}$is more competitive than $\mathrm{Ag}^{+}$(lower $\Delta \mathrm{Gs}$ for the former than the latter), it cannot outcompete $\mathrm{Na}^{+}$(all positive $\Delta \mathrm{Gs}$ ). Adding the results evaluated for the coinage cations to those of their alkali counterparts, the order of metals' affinity to salinomycin in low-polarity solvents becomes: $\mathrm{Li}^{+}>\mathrm{Cu}^{+}>\mathrm{Na}^{+}>\mathrm{K}^{+}>\mathrm{Au}^{+}>\mathrm{Ag}^{+}>\mathrm{Rb}^{+}>\mathrm{Cs}^{+}$, whereas some reordering takes place in high-dielectric media: $\mathrm{Li}^{+} \geq \mathrm{Na}^{+}>\mathrm{K}^{+}>\mathrm{Cu}^{+}>\mathrm{Au}^{+}>\mathrm{Ag}^{+}>\mathrm{Rb}^{+}>\mathrm{Cs}^{+}$.

\subsection{Salinomycin vs. Monensin}

Recently we studied the process of complexation of monensin-another representative of ionophore antibiotics, analogous to that of salinomycin-with the same series of 
monovalent metal cations, where the trends of changes in metal cation affinity to the host ligand were established [35]. Although generally similar, the two ionophores exhibit some variances in their complexation behavior, differing quite significantly in their flexibility. Monensin appears to be much more rigid than salinomycin forcing the incoming metal cations (regardless of their coordination preferences) to adopt a six-coordinated geometry with octahedrally arranged oxygen-containing groups. On the other hand, in salinomycin monovalent metal complexes, it is the cation that dictates the coordination geometry. As seen (above) the coordination numbers of different metals are scattered between $2\left(\mathrm{Au}^{+}\right)$, $4\left(\mathrm{Li}^{+}\right.$and $\left.\mathrm{Cu}^{+}\right), 5 / 6\left(\mathrm{Na}^{+}, \mathrm{K}^{+}, \mathrm{Ag}^{+}\right), 6 / 7\left(\mathrm{Rb}^{+}\right)$and $7 / 8\left(\mathrm{Cs}^{+}\right)$. Along the same vein, salinomycin is flexible enough allowing the metal ions to accept and incorporate as a part of their coordination sphere water molecule(s). Differences in coordination pattern reflect on the relative affinity of metal cations to the two ionophores. Although the sequence is the same for non-polar solvents $\left(\mathrm{Li}^{+}>\mathrm{Cu}^{+}>\mathrm{Na}^{+}>\mathrm{K}^{+}>\mathrm{Au}^{+}>\mathrm{Ag}^{+}>\mathrm{Rb}^{+}>\mathrm{Cs}^{+}\right)$, it is different in high dielectric media: $\mathrm{Na}^{+}>\mathrm{Li}^{+}>\mathrm{K}^{+}>\mathrm{Cu}^{+}>\mathrm{Au}^{+}>\mathrm{Ag}^{+}>\mathrm{Rb}^{+}>\mathrm{Cs}^{+}$(monensin) and $\mathrm{Li}^{+} \geq \mathrm{Na}^{+}>\mathrm{K}^{+}>\mathrm{Cu}^{+}>\mathrm{Au}^{+}>\mathrm{Ag}^{+}>\mathrm{Rb}^{+}>\mathrm{Cs}^{+}$(salinomycin). The calculations revealed that the change in solvent polarity may favor the binding of certain metal ions and this finding can be explored under laboratory conditions. The growth of crystals suitable for X-ray diffraction studies will bring new insights into the structural chemistry of salinomycin in the solid state.

\section{Methods}

\subsection{Gibbs Free Energy Change for the Reaction Modeled}

The cation exchange free energy for Equation (1) in a medium characterized by an effective dielectric constant $\varepsilon$ can be calculated as a sum of electronic $\left(\Delta \mathrm{G}^{1}\right)$ and solvation $\left(\Delta \Delta G^{\varepsilon}\right.$ solv $)$ effects (Equation (2)):

$$
\Delta \mathrm{G}^{\varepsilon}=\Delta \mathrm{G}^{1}+\Delta \Delta \mathrm{G}^{\varepsilon} \text { solv }
$$

where $\Delta G^{1}$ is the gas-phase free energy for Equation (1) (see below in next subsection), whereas $\Delta \Delta G^{\varepsilon}$ solv is the difference in the solvation free energies $\Delta G^{\varepsilon}$ solv of the products and reactants in the same process (Equation (3)).

$$
\begin{gathered}
\Delta \Delta \mathrm{G}^{\varepsilon} \text { solv }=\Delta \mathrm{G}^{\mathcal{\varepsilon}} \text { solv }([\text { SalM }])+\Delta \mathrm{G}^{\varepsilon} \text { solv }\left(\left[\mathrm{Na}^{+} \text {-solution }\right]\right) \\
-\Delta \mathrm{G}^{\varepsilon} \text { solv }([\text { SalNa }])-\Delta \mathrm{G}^{\varepsilon} \text { solv }\left(\left[\mathrm{M}^{+} \text {-solution }\right]\right)
\end{gathered}
$$

Equation (1) was modeled in different dielectric environments ranging from non-polar solvents such as cyclohexane $(\varepsilon \approx 2)$ and diethyl ether $(\varepsilon \approx 4)$ to highly polar counterparts such as methanol $(\varepsilon \approx 32)$ and water $(\varepsilon \approx 78)$. The positive Gibbs free energy change for Equation (1) suggests a $\mathrm{Na}^{+}$-selective ligand while the negative value implies an $\mathrm{M}^{+}$selective ionophore. Note that our aim is to derive reliable trends of changes in the free energy of metal substitution (i.e., ranking the metal cations with respect to their relative affinity to salinomycin), rather than evaluating the absolute free energies of metal exchange. Such an approach has been successfully applied to various metal-containing systems such as monensin [35], macrocyclic cage molecules [37], model ion channels [38,39] and metalloproteins $[40,41]$.

\subsection{DFT/PCM Calculations}

The Gaussian 09 suite of programs [42] was employed in performing the calculations. All the metal constructs were fully optimized in the gas phase at the B3LYP $/ 6-31+G(d, p)$ level of theory producing the respective electronic energies, $\mathrm{E}_{\text {elect }}$. The SDD basis set and the effective core potential were used for the heavier cations from the group IA $\left(\mathrm{Rb}^{+}\right.$and $\left.\mathrm{Cs}^{+}\right)$ and IB $\left(\mathrm{Ag}^{+}\right.$and $\left.\mathrm{Au}^{+}\right)$. This combination of method/basis set was selected for the current computations as it proved reliable and performed very well in reproducing the experimental structures of a series of $\mathrm{Na}^{+} / \mathrm{M}^{+}$complexes similar to salinomycin ionophore-monensin, studied in our recent work [35]. The vibrational frequencies of the metal complexes were 
evaluated at the same level of theory. No imaginary frequency was detected for any of the optimized constructs signifying a local minimum of the potential energy surface. The vibrational frequencies were employed in evaluating the thermal energies, including the zero-point energy, $\mathrm{E}_{\mathrm{T}}$, and entropy, $\mathrm{S}$. These values were used in estimating the gas phase Gibbs free energies for Equation (1), $\Delta \mathrm{G}^{1}$, at room temperature, $\mathrm{T}=298.15 \mathrm{~K}$, according to Equation (4):

$$
\Delta \mathrm{G}^{1}=\Delta \mathrm{E}_{\text {elect }}+\Delta \mathrm{E}_{\mathrm{T}}-\mathrm{T} \Delta \mathrm{S}
$$

where $\Delta \mathrm{E}_{\text {elect }}, \Delta \mathrm{E}_{\mathrm{T}}$, and $\Delta \mathrm{S}$ are the respective differences between the products and reactants. The solvation effects were assessed by employing polarizable continuum model calculations utilizing SMD scheme [43] as implemented in Gaussian 09.

Single point calculations of each gas-phase optimized structure were conducted in each solvent. The differences between the gas phase and solution energies yielded the free energies of solvation of the complex, $\Delta \mathrm{G}^{\varepsilon}$ solv (Tables 5 and 6). Notably, the experimentally determined solvation free energies for the metal cations in aqueous solution $\left(\mathrm{Li}^{+}, \mathrm{Na}^{+}\right.$, $\mathrm{K}^{+}, \mathrm{Rb}^{+}, \mathrm{Cs}^{+}$, and $\left.\mathrm{Ag}^{+}\right)$were used in the computations. For other cations $\left(\mathrm{Cu}^{+}\right.$and $\left.\mathrm{Au}^{+}\right)$and solvents, the estimated values were used, where the ratios in the theoretically evaluated quantities along with the experimental values were used to determine the respective $\Delta \mathrm{G}^{\varepsilon}$ solv of $\left[\mathrm{M}^{+} / \mathrm{Na}^{+}\right.$-solution] [35]. Of note, such a calculation protocol utilizing a thermodynamic cycle that employs the experimental solvation free energies of some of participating entities (where available), has proven quite dependable in reproducing the experimental thermodynamic data [44]. The basis set superposition error (BSSE) for this type of exchange reaction (Equation (1)) was found to be negligible [38] and, therefore, was not considered in the current calculations.

Table 5. Gibbs free energies of solvation evaluated from PCM calculations for salinomycin complexes containing one water molecule in solvents with different dielectric constants (in $\mathrm{kcal} / \mathrm{mol}$ ).

\begin{tabular}{ccccc}
\hline \multirow{2}{*}{ SalM-W } & \multicolumn{4}{c}{$\Delta \mathbf{G}^{\text {solv }}$} \\
\cline { 2 - 5 } & Cyclohexane & Diethylether & Methanol & Water \\
\hline $\mathrm{Li}$ & -19.97 & -27.48 & -39.73 & -24.86 \\
$\mathrm{Na}$ & -19.10 & -26.06 & -37.70 & -22.72 \\
$\mathrm{~K}$ & -18.49 & -25.17 & -36.98 & -22.24 \\
$\mathrm{Rb}$ & -19.29 & -26.42 & -40.78 & -26.00 \\
$\mathrm{Cs}$ & -19.42 & -26.75 & -40.97 & -26.20 \\
$\mathrm{Cu}$ & -19.73 & -27.12 & -44.50 & -20.88 \\
$\mathrm{Ag}$ & -19.49 & -26.74 & -39.99 & -25.21 \\
$\mathrm{Au}$ & -19.82 & -27.36 & -42.13 & -27.63 \\
\hline $\mathrm{G}^{\text {solv }}=\mathrm{E}$ & & &
\end{tabular}

$\Delta \mathrm{G}^{\text {solv }}=\mathrm{E}_{\text {solvent }}-\mathrm{E}_{\text {gas-phase. }}$

Table 6. Gibbs free energies of solvation evaluated from PCM calculations for salinomycin complexes containing two water molecules in solvents with different dielectric constants (in $\mathrm{kcal} / \mathrm{mol}$ ).

\begin{tabular}{ccccc}
\hline \multirow{2}{*}{ SalM-W } & \multicolumn{4}{c}{$\Delta \mathbf{G}^{\text {solv }}$} \\
\cline { 2 - 4 } & Cyclohexane & Diethylether & Methanol & Water \\
\hline $\mathrm{Li}$ & -20.50 & -28.79 & -45.65 & -30.76 \\
$\mathrm{Na}$ & -19.23 & -26.52 & -43.59 & -27.90 \\
$\mathrm{~K}$ & -19.31 & -26.91 & -43.83 & -28.26 \\
$\mathrm{Rb}$ & -20.05 & -28.07 & -46.11 & -31.25 \\
$\mathrm{Cs}$ & -20.17 & -28.27 & -45.98 & -31.21 \\
$\mathrm{Cu}$ & -19.53 & -27.17 & -50.19 & -35.30 \\
$\mathrm{Ag}$ & -19.51 & -27.09 & -45.93 & -30.65 \\
$\mathrm{Au}$ & -20.50 & -29.01 & -48.56 & -34.44 \\
\hline
\end{tabular}

$\Delta \mathrm{G}^{\text {solv }}=\mathrm{E}_{\text {solvent }}-\mathrm{E}_{\text {gas-phase }}$. 


\section{Conclusions}

The quantum chemical study performed disclosed the nature of the monovalent metal ions as the major factor in governing the affinity of salinomycinate anion towards group IA and IB cations. The smaller ions possessing higher positive charge density and higher ligand preference $\left(\mathrm{Li}^{+}\right.$and $\left.\mathrm{Cu}^{+}\right)$predominantly coordinate in an environment with lower dielectric properties. In polar solvents, $\mathrm{Li}^{+}$ions are superior to $\mathrm{Na}^{+}$, while the heavier alkali metal ions and their group IB counterparts are weaker competitors. The internal cavity of salinomycinate ion appears to be very flexible accommodating one or two water molecules that occupy, in addition to salinomycin binding groups, the inner coordination sphere of the metal center. The latter is crucial for the complex geometry where the metal coordination number varies from two in $\mathrm{SalAu}-\mathrm{W}_{1} / \mathrm{W}_{2}$ to eight in SalCs- $\mathrm{W}_{1}$.

Author Contributions: Conceptualization, I.P. and T.D.; methodology and analysis, T.D. and D.C.; writing - original draft preparation, review and editing, I.P., T.D., D.C. and P.D. All authors have read and agreed to the published version of the manuscript.

Funding: This research and APC were funded by the Bulgarian National Science Fund (Grant number KP-06-H29/3).

Institutional Review Board Statement: Not applicable.

Informed Consent Statement: Not applicable.

Data Availability Statement: Data is available from the authors upon request.

Conflicts of Interest: The authors declare no conflict of interest.

Sample Availability: Not available.

\section{References}

1. Miyazaki, Y.; Shibuya, M.; Sugawara, H.; Kawaguchi, O.; Hirsoe, C. Salinomycin, a new polyether antibiotic. J. Antibiot. 1974, 27, 814-821. [CrossRef]

2. Chappel, L.R. The site of action of the anticoccidial salinomycin (Coxistac). J. Parasitol. 1979, 65, 137-143. [CrossRef] [PubMed]

3. Long, P.L.; Jeffers, T.K. Studies on the stage of action of ionophorous antibiotics against Eimeria. J. Parasitol. 1982, 68, 363-371. [CrossRef] [PubMed]

4. Coombs, G.H.; Müller, S. Recent advances in the search for new anti-coccidial drugs. Int. J. Parasitol. 2002, 32, 497-508. [CrossRef]

5. Mahmoudi, N.; de Julian-Ortiz, J.-V.; Ciceron, L.; Galvez, J.; Mazier, D.; Danis, M.; Derouin, F.; Garcia-Domenech, R. Identification of new antimalarial drugs by linear discriminant analysis and topological virtual screening. J. Antimicrob. Chemother. 2006, 57, 489-497. [CrossRef] [PubMed]

6. $\quad$ D'Alessandro, S.; Corbett, Y.; Ilboudo, D.P.; Misiano, P.; Dahiya, N.; Abay, S.M.; Habluetzel, A.; Grande, R.; Gismondo, M.R.; Dechering, K.J.; et al. Salinomycin and other ionophores as a new class of antimalarial drugs with transmission-blocking activity. Antimicrob. Agents Chemother. 2015, 59, 5135-5144. [CrossRef]

7. Yuan, C.; Huang, X.; Zhai, R.; Ma, Y.; Xu, A.; Zhang, P.; Yang, Q. In Vitro antiviral activities of salinomycin on porcine epidemic diarrhea virus. Viruses 2021, 13, 580. [CrossRef]

8. Gupta, P.B.; Onder, T.T.; Jiang, G.; Tao, K.; Kuperwasser, C.; Weinberg, R.A.; Lander, E.S. Identification of selective inhibitors of cancer stem cells by high-throughput screening. Cell 2009, 138, 645-659. [CrossRef] [PubMed]

9. Lu, D.; Choi, M.Y.; Yu, J.; Castro, J.E.; Kipps, T.J.; Carson, D.A. Salinomycin inhibits Wnt signaling and selectively induces apoptosis in chronic lymphocytic leukemia cells. Proc. Natl. Acad. Sci. USA 2011, 108, 13253-13257. [CrossRef]

10. Tang, Q.L.; Zhao, Z.Q.; Li, J.C.; Liang, Y.; Yin, J.Q.; Zou, C.Y.; Xie, X.B.; Zeng, Y.X.; Shen, J.N.; Kang, T.; et al. Salinomycin inhibits osteosarcoma by targeting its tumor stem cells. Cancer Lett. 2011, 311, 113-121. [CrossRef]

11. Naujokat, C.; Steinhart, R. Salinomycin as a drug for targeting human cancer stem cells. J. Biomed. Biotechnol. 2012, $2012,950658$. [CrossRef] [PubMed]

12. Zhou, S.; Wang, F.; Wong, E.T.; Fonkem, E.; Hsieh, T.C.; Wu, J.M.; Wu, E. Salinomycin: A novel anti-cancer agent with known anti-coccidial activities. Curr. Med. Chem. 2013, 20, 4095-4101. [CrossRef] [PubMed]

13. Zhang, C.; Tian, Y.; Song, F.; Fu, C.; Han, B.; Wang, Y. Salinomycin inhibits the growth of colorectal carcinoma by targeting tumor stem cells. Oncol. Rep. 2015, 34, 2469-2476. [CrossRef] [PubMed]

14. Najumudeen, A.K.; Jaiswal, A.; Lectez, B.; Oetken-Lindholm, C.; Guzman, C.; Siljamaki, E.; Posada, I.M.D.; Lacey, E.; Aittkallio, T.; Abankwa, D. Cancer stem cell drugs target K-ras signaling in a stemness context. Oncogene 2016, 35, 5248-5262. [CrossRef]

15. Dewangan, J.; Srivastava, S.; Rath, S.K. Salinomycin: A new paradigm in cancer therapy. Tumour. Biol. 2017, $39,1010428317695035$. [CrossRef] 
16. Mai, T.T.; Hamai, A.; Hienzsch, A.; Caneque, T.; Muller, S.; Wicinski, J.; Cabaud, O.; Leroy, C.; David, A.; Acevedo, V.; et al. Salinomycin kills cancer stem cells by sequestering iron in lysosomes. Nat. Chem. 2017, 9, 1025-1033. [CrossRef]

17. Lee, H.G.; Shin, S.J.; Chung, H.W.; Kwon, S.H.; Cha, S.D.; Lee, J.E.; Cho, C.H. Salinomycin reduces stemness and induces apoptosis on human ovarian cancer stem cell. J. Gynecol. Oncol. 2017, 28, e14. [CrossRef]

18. Liu, L.; Wang, Q.; Mao, J.; Qin, T.; Sun, Y.; Yang, J.; Han, Y.; Li, L.; Li, Q. Salinomycin suppresses cancer cell stemness and attenuates TGF-beta-induced epithelial-mesenchymal transition of renal cell carcinoma cells. Chem. Biol. Interact. 2018, 296, 145-153. [CrossRef]

19. Zhou, J.; Liu, S.; Wang, Y.; Dai, W.; Zou, H.; Wang, S.; Zhang, J.; Pan, J. Salinomycin effectively eliminates cancer stem-like cells and obviates hepatic metastasis in uveal melanoma. Mol. Cancer 2019, 18, 159. [CrossRef]

20. Liu, Y.; Hao, Y.; Li, Y.; Zheng, Y.; Dai, J.; Zhong, F.; Wei, W.; Fang, Z. Salinomycin induces autophagic cell death in salinomycinsensitive melanoma cells through inhibition of autophagic flux. Sci. Rep. 2020, 10, 18515. [CrossRef]

21. Li, K.; Pang, L.; Pan, X.; Fan, S.; Wang, X.; Wang, Q.; Dai, P.; Gao, W.; Gao, J. GE11 modified PLGA/TPGS nanoparticles targeting delivery of salinomycin to breast cancer cells. Technol. Cancer Res. Treat. 2021, 20, 15330338211004954. [CrossRef] [PubMed]

22. Wang, H.; Zhang, H.; Zhu, Y.; Wu, Z.; Cui, C.; Cai, F. Anticancer mechanisms of salinomycin in breast cancer and its clinical applications. Front. Oncol. 2021, 11, 654428. [CrossRef] [PubMed]

23. Pinkerton, M.; Stenrauf, L.K. Molecular structure of monovalent metal cation complexes of monensin. J. Mol. Biol. 1970, 49, 533-546. [CrossRef]

24. Lutz, W.K.; Winkler, F.K.; Dunitz, J.D. Crystal structure of the antibiotic monensin. Similarities and differences between free acid and metal complex. Helv. Chim. Acta 1971, 54, 1103-1108. [CrossRef]

25. Duax, W.L.; Smith, G.D.; Strong, P.D. Complexation of metal ions by monensin. Crystal and molecular structure of hydrated and anhydrous crystal forms of sodium monensin. J. Am. Chem. Soc. 1980, 102, 6725-6729. [CrossRef]

26. Walba, D.M.; Hermsmeier, M.; Haltiwanger, R.C.; Noordik, J.H. Crystal structures of monensin B lithium and silver salts. J. Org. Chem. 1986, 51, 245-247. [CrossRef]

27. Pangborn, W.; Duax, W.; Langs, D. The hydrated potassium complex of the ionophore monensin A. J. Am. Chem. Soc. 1987, 109, 2163-2165. [CrossRef]

28. Huczynski, A.; Ratajczak-Sitarz, M.; Katrusiak, A.; Brzezinski, B. Molecular structure of the 1:1 inclusion complex of monensin A sodium salt with acetonitrile. J. Mol. Struct. 2007, 832, 84-89. [CrossRef]

29. Huczynski, A.; Ratajczak-Sitarz, M.; Katrusiak, A.; Brzezinski, B. Molecular structure of the 1:1 inclusion complex of monensin A lithium salt with acetonitrile. J. Mol. Struct. 2007, 871, 92-97. [CrossRef]

30. Huczynski, A.; Ratajczak-Sitarz, M.; Katrusiak, A.; Brzezinski, B. Molecular structure of rubidium six-coordinated dihydrate complex with monensin A. J. Mol. Struct. 2008, 883, 224-229. [CrossRef]

31. Paulus, E.F.; Kurz, M.; Matter, H.; Vertesy, L. Solid-state and solution structure of the salinomycin-sodium complex: Stabilization of different conformers for an ionophore in different environments. J. Am. Chem. Soc. 1998, 120, 8209-8221. [CrossRef]

32. Mitani, M.; Yamanishi, T.; Miyazaki, Y. Salinomycin: A new monovalent cation ionophore. Biochem. Biophys Res. Comm. 1975, 66, 12311236. [CrossRef]

33. Shannon, R.D. Revised effective ionic radii and systematic studies in interatomic distances in halides and chalcogenides. Acta Cryst. 1976, A32, 751-767. [CrossRef]

34. Gagne, O.C.; Hawthorne, F.C. Empirical Lewis acid strengths for 135 cations bonded to oxygen. Acta Cryst. B 2017, 73, 956-961. [CrossRef] [PubMed]

35. Dudev, T.; Cheshmedzhieva, D.; Dimitrova, R.; Dorkov, P.; Pantcheva, I. Factors governing the competition between group IA and IB cations for monensin A: A DFT/PCM study. RSC Adv. 2020, 10, 5734-5741. [CrossRef]

36. Laguna, A. Modern Supramolecular Gold Chemistry: Gold-Metal Interactions and Applications, 1st ed.; WILEY-VCH Verlag GmbH \& Co. KgaA: Weinheim, Germany, 2008.

37. Angelova, S.E.; Nikolova, V.K.; Dudev, T.M. Determinants of the host-guest interactions between $\alpha$-, $\beta$ - and $\gamma$-cyclodextrins and group IA, IIA and IIIA metal cations: A DFT/PCM study. Phys. Chem. Chem. Phys. 2017, 19, 15129-15136. [CrossRef]

38. Dudev, T.; Lim, C. Determinants of $\mathrm{K}^{+}$vs. $\mathrm{Na}^{+}$selectivity in potassium channels. J. Am. Chem. Soc. 2009, $131,8092-8101$. [CrossRef] [PubMed]

39. Dudev, T.; Lim, C. Ion selectivity strategies of sodium channel selectivity filters. Acc. Chem. Res. 2014, 47, 3580-3587. [CrossRef] [PubMed]

40. Dudev, T.; Cheshmedzhieva, D.; Doudeva, L. Competition between abiogenic $\mathrm{Al}^{3+}$ and native $\mathrm{Mg}^{2+}, \mathrm{Fe}^{2+}$ and $\mathrm{Zn}^{2+}$ ions in protein binding sites: Implications for aluminum toxicity. J. Mol. Model. 2018, 24, 55. [CrossRef]

41. Dudev, T.; Grauffel, C.; Lim, C. How $\mathrm{Pb}^{2+}$ binds and modulates properties of $\mathrm{Ca}^{2+}$-signaling proteins. Inorg. Chem. 2018, 57, 14798-14809. [CrossRef]

42. Frisch, M.J.; Trucks, G.W.; Schlegel, H.B.; Scuseria, G.E.; Robb, M.A.; Cheeseman, J.R.; Montgomery, J.A., Jr.; Vreven, T.; Kudin, K.N.; Burant, J.C.; et al. Gaussian 09; Gaussian Inc.: Pittsburgh, PA, USA, 2009.

43. Marenich, A.V.; Cramer, C.J.; Truhlar, D.G. Universal solvation model based on solute electron density and on a continuum model of the solvent defined by the bulk dielectric constant and atomic surface tensions. J. Phys. Chem. B 2009, 113, 63786396. [CrossRef] [PubMed]

44. Kircheva, N.; Dudev, T. Novel insights into gallium's mechanism of therapeutic action: A DFT/PCM study of the interaction between $\mathrm{Ga}^{3+}$ and ribonucleotide reductase substrates. J. Phys. Chem. B 2019, 123, 5444-5451. [CrossRef] [PubMed] 